\title{
Tintinnina (Ciliophora, Protista) of the North Sea during the spring of 1986
}

\author{
T. A. Cordeiro ${ }^{1} \&$ R. Sassi ${ }^{2}$ \\ ${ }^{1}$ Centro de Estudos do Mar, Universidade Federal do Paraná; Av. Beira Mar s/n, \\ 83255-000 Pontal do Sul - PR, Brasil \\ ${ }^{2}$ NEPREMAR, Universidade Federal da Paraíba; Campus Universitário, \\ 58059-900 João Pessoa - PB, Brasil
}

\begin{abstract}
This work is the first of a series in which the distribution patterns and the importance of the Tintinnina in the trophic chain of the North Sea are evaluated. In agreement with Foissner (1994), who stated "Most ecological papers on planktonic protozoans lack reliable identifications and modern nomenclature ...", the series will start with the results of a taxonomic revision. Illustrations and brief descriptions of the 23 Tintinnina species found in this analysis are given, as well as comments about species identification. Differences between the present results and the previous work of Lindley (1975) can indicate some changes in the species structure. A higher number of species was found than that found by Lindley (1975) in seasonal samplings.
\end{abstract}

\section{INTRODUCTION}

Despite many works on Tintinnina, including those on the North Sea species (e.g. Jørgensen, 1899; Brandt, 1907; Hofker, 1931), the taxonomy of the group is far from being accepted as definite (Laval-Peuto \& Brownlee, 1986). The system proposed by Kofoid \& Campbell $(1929,1939)$ is based solely on the morphology of the lorica. However, we know today that variations in the shape and size of the lorica occur with frequency due to changes in temperature, salinity, food concentration (Gold \& Morales, 1975), cellular division rates (Gold, 1970; Verity, 1987; Pierce \& Turner, 1992), polymorphism in biological cycles (Laval-Peuto, 1981), and the formation of resistance spores (Kamiyama \& Aizawa, 1990).

Some pioneer works such as Daday (1887), Brandt (1907), Schulz \& Wulff (1929) and Hofker (1931) called attention to the inter-specific variations in the shape of the lorica and followed the use of cell morphology to make safer descriptions and identifications. Usually, however, formaldehyde and lugol are used as preserving agents in marine biology, which retains only the lorica of the Tintinnina, giving a wide margin for the occurrence of synonyms, such as those included in the revisions of Kofoid \& Campbell $(1929,1939)$ and which have been adopted by most of the authors who followed them. At present, the silver-protargol technique is being used more frequently, permitting comparisons of the tintinnids at the infracilliature level (Brownlee, 1977; Snyder \& Brownlee, 1991; Choi et al., 1992); however, the number of works is still insufficient to attempt a new revision based on the morphology of the cell. Everything indicates that the lorica morphology shall remain, for the time being, the usual way to identify tintinnids. 
In this context, it seems appropriate to present the results of a taxonomic revision of a collection from the whole North Sea, taken in spring of 1986, where only the lorica morphology was considered. This work should become, in agreement with Foissner (1994), a basis for the discussion about the ecology of the Tintinnina in the North Sea. This revision does not solve all the problems concerning the identification of Tintinnina from the North Sea, but, instead, stresses the necessity for more investigations in the future. The figures, descriptions and original references may prove to be helpful for future studies.

\section{MATERIAL AND METHODS}

The major objective of the German ZISCH program facronym for "Zirkulation und Schadstoffumsatz in der Nordsee" - "Circulation and Pathways of Pollutants in the North Sea") was to actualize the existing data on the environmental conditions in the North Sea in relation to anthropic activity. Its fulfillment involved some research institutes of the $\mathrm{Fe}$ deral Republic of Germany and depended on the simultaneous mission of three oceanographic vessels: F.S. "Valdivia", F.S. "Gauss" and the F.S. "Planet". One of the participating institutes was the Biological Station of Helgoland (Biologische Anstalt Helgoland), where the microplankton samples of this work are deposited. The program was accomplished in two stages, one in spring (1986) and the other in winter (1987). The present study was made using as basis 129 oceanographic stations distributed in radials from the geographical center of the North Sea, during the late spring, between May 2nd and June 3rd, 1986. A total of 265 samples from 60 stations was selected for the analysis of the Tintinnina (Fig. 1).

Microplankton was collected with 5-liter Niskin bottles at 5 depths per station. The sampled depths varied according to the station and the thermocline depths. In shallow stations, in depths less than $30 \mathrm{~m}$, only 3 or 4 depths were sampled. The samples were concentrated with a mesh of $20 \mu \mathrm{m}$ and kept in $2 \%$ formaldehyde neutralised with borax. Microscopic analysis was carried out with an inverted microscope according to the Utermöhl (1958) technique, using sedimentation chambers of 10,25 and $50 \mathrm{ml}$. In order to permit the identification of the species level, it was necessary to photograph different specimens with a common reflex camera, adapted to the lens of the microscope. The identification of the Tintinnina was based principally on the works of Jørgensen (1899, 1924, 1940), Brandt (1906, 1907), Meunier (1919), Kofoid \& Campbell (1929, 1939), Hofker (1931), Candeias (1932), Gaarder (1946), Marshall (1969) and Souto (1981), using only the lorica morphology as diagnostic criterion. The systematic position of the suborder Tintinnina adopted in this work was proposed by Montagnes \& Lynn (1991):

PROTISTA kingdom

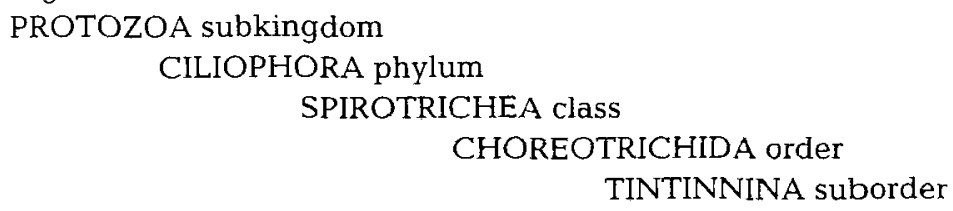




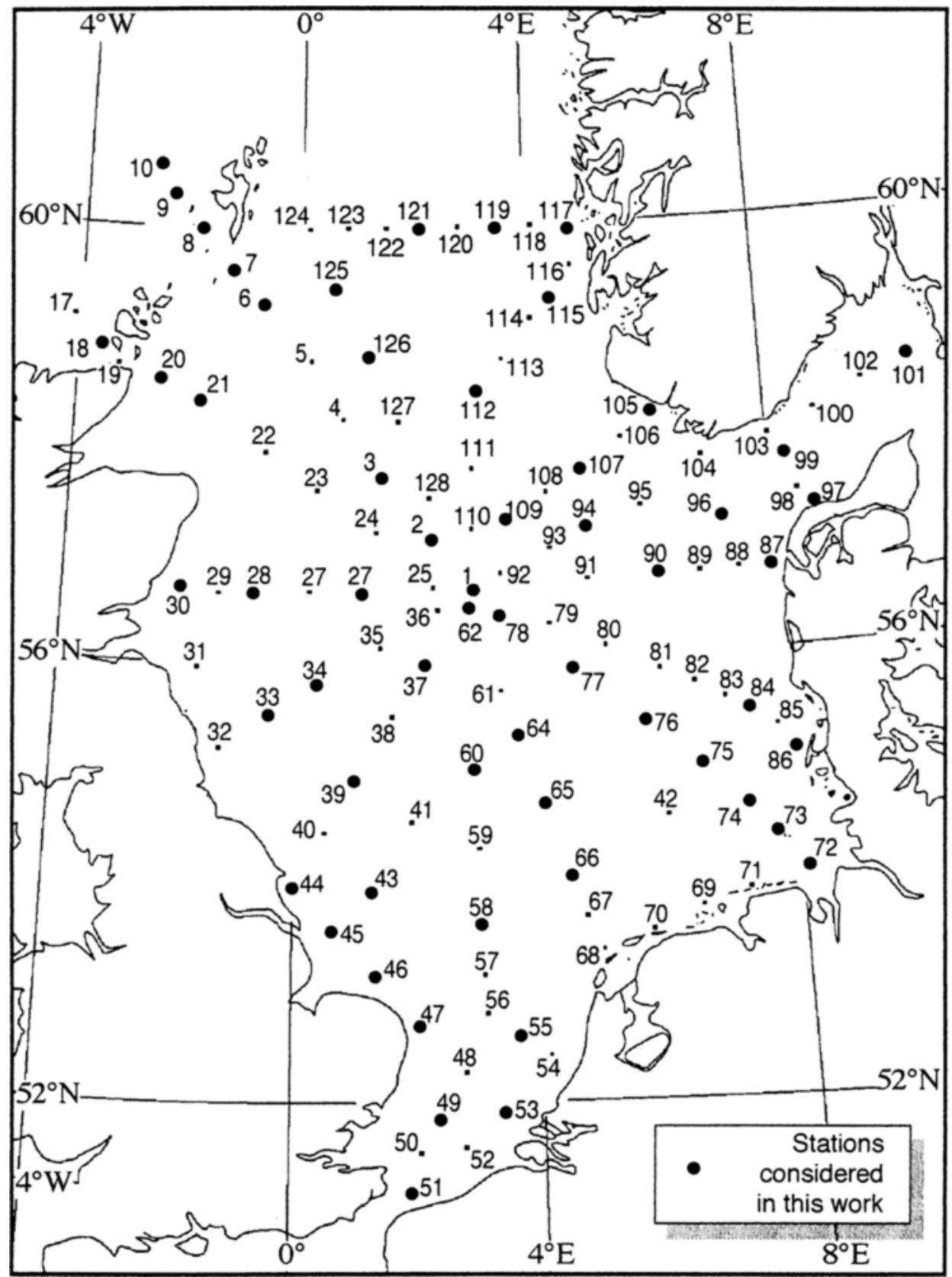

Fig. 1. Position of the oceanographic stations of the ZISCH program, from May 2nd to June 3rd, 1986 


\section{RESULTS}

Following the analysis of 265 samples of microplankton, 23 species were identified, distributed in 9 families and 12 genera, which are hereby listed as follows:

\section{Family Tintinnididae Kofoid \& Campbell, 1929}

Leprotintinnus pellucidus (Cleve, 1899) (Fig. 2 a). Few loricae were found during the analysis of the samples of the ZISCH program; all occurrences were from the Baltic Sea and the coast of Norway. A notable characteristic of this species is the open lorica in the two extremities, the diameter diminishes from the oral to the aboral region, the upper part is hyaline and the presence of adhered particles increases gradually in the lower region, the aboral aperture is slightly enlarged and covered with particles. The mean ratio between length and breadth is 6.3 .

Family Codonellidae Kent, 1882

Tintinnopsis beroidea Stein, 1867 (Fig. 2 b). The lorica is cylindrical, widening slightly in direction of the oral aperture and ending in a cone whose profile resembles an isosceles triangle: being totally covered by particles such as grains of sand, which give the surface a granulated appearance. The length is quite variable during the development of the cell, which gives room for the creation of much synonymity. However, rarely does the length exceed $120 \mu \mathrm{m}$.

T. cf cylindrica Daday, 1887 (Fig. 2 c). Only one lorica of this species was found on the surface of station 97 . The lorica has a granulated appearance as a result of the presence of adhered particles, is uniformly cylindrical up to the aboral cone, where a pronounced peduncle is located which corresponds to approximately $1 / 5$ of total length and characterizes this species.

T. nana Lohmann, 1908 (Fig. 2 d) occurred only at station 45. The lorica is covered with material grasped by the cell and has small dimensions (Table 1), is the shape of a wedge with a slightly rounded profile. The oral region represents the widest part, from here on the diameter diminishes gradually until the lorica terminates in a slightly rounded aboral end.

T. parvula (Jørgensen, 1899) (Fig. 2 e). The lorica is covered by particles as are all other Tintinnopsis and is slightly bigger than $T$. nana. The widest part is located near the middle region, giving the lorica the appearance of a sectioned ellipse, and the aboral region is conical.

T. cf spiralis (Meunier, 1910) (Fig. 2 f). Only one lorica of this species was found at a depth of $300 \mathrm{~m}$ at station 99 , which prevents a reliable identification. The lorica is elongated; from the oral aperture until the superior third the diameter diminishes by around $1 / 5$, increasing again until the inferior third and henceforth diminishing until terminating in a sharp angle. This specimen differs from that described by Marshall (1969), which has spiral striation in the wall of the lorica.

T. tubulosa Levander, 1900 (Fig. 2 g) was restricted to stations 45 and 47, however in densities which vary between 19 and 78 ind $\cdot l^{-1}$. The lorica is approximately cylindrical, showing a slight narrowing beneath the oral aperture, with a small ratio between length 

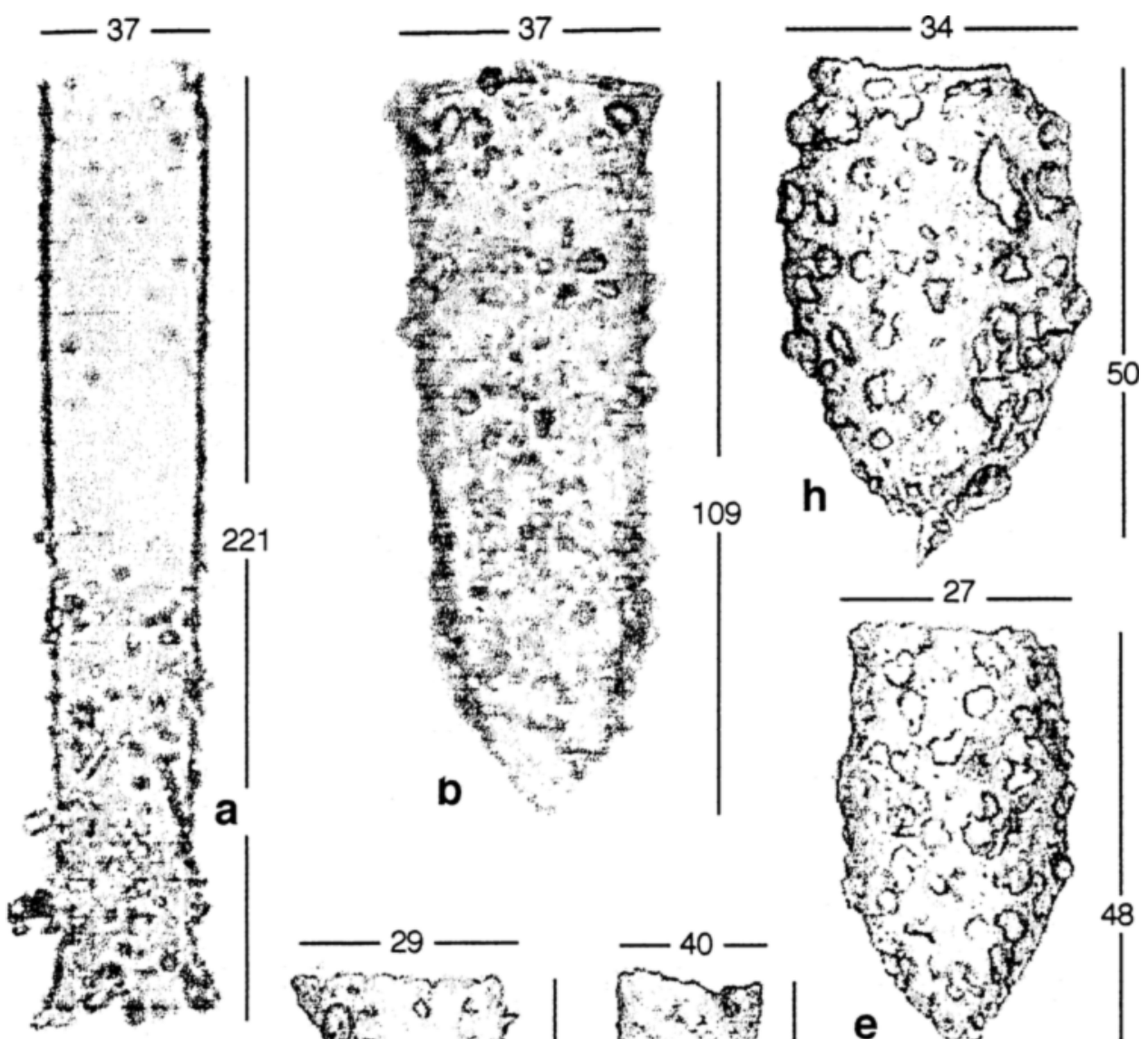

109
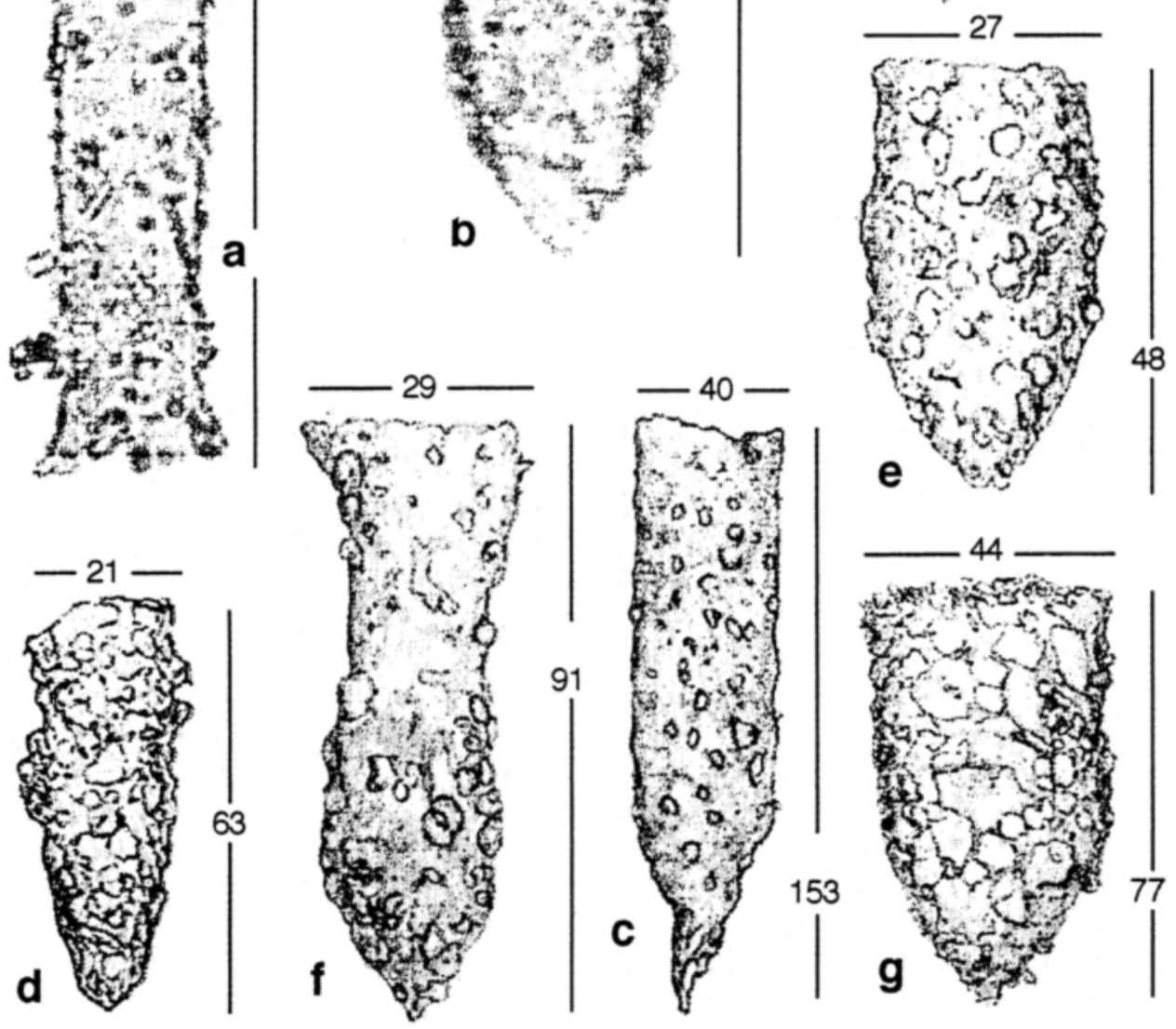

Fig. 2. Tintinnididae, Leprotintinnus pellucidus (a) ${ }_{i}$ Codonellidae, Tintinnopsis beroidea (b), T. of cylindrica (c), T. nana (d), T. parvula (e), T. cf spiralis (f), T. tubulosa (g), Tintinnopsis $s p(\mathrm{~h})$. Distances in $\mu \mathrm{m}$ 
and diameter in relation to all other species of Tintinnina described in this work (1.8); as such, length rarely attains double the diameter measured in the oral region.

Tintinnopsis sp. (Fig. $2 \mathrm{~h}$ ) occurred in small quantities in the stations in the English Channel, in the German Bight, and along the coast of Norway. As in all the other Tintinnopsis, the lorica was completely covered with particles. The broadest part is in the middle region, tapering very little in direction of the oral aperture and strongly toward the base. The inferior part of the lorica resembles one half of an ellipse.

\section{Family Codonellopsidae Kofoid \& Campbell, 1929}

Stenosemella nivalis (Meunier, 1910) (Fig. 3 a). This was the most abundant species in the samples, superseding all the others in the number of individuals sampled and frequency in the analysed stations, appearing in more than $52 \%$ of the samples. The lorica is small and covered with foreign particles, the genus Stenosemella differing from Tintinnopsis in the presence of an oral collar, normally hyaline and free of encrustations. The ratio between length and breadth is small (1.3), the largest part being under the oral collar tapering until the base, forming an open angle.

Stenosemella producta (Meunier, 1919) (Fig. 3 b) occurred in only 5 samples. The morphological pattern of the lorica is similar to that of $S$. nivalis, however slightly longer and narrower, with an evident shoulder near the collar.

Codonellopsis ovata Jørgensen, 1924 (Fig. 3 c). Few individuals of this species were found, in depths of about $200 \mathrm{~m}$ at stations $\mathrm{n}^{\circ} 115$ and 117 . Of small dimensions, the lorica is spheric and lightly covered by particles. The oral collar is quite fragile and often hard to observe.

Family Coxliellidae Kofoid \& Campbell, 1929

Coxliella pseudoannulata (Jørgensen, 1901) (Fig. 3 d). This species occurred only at stations near the Norwegian coast. The lorica is banded in a spiral formation in which the number of rings is quite variable. The wall of the bands shows an alveolar structure, which is a distinctive characteristic of the genus Coxliella. The separation between the cylinder and aboral cone is well defined and located in a region between half and lower third of the length.

Helicostomella subulata (Ehrenberg, 1833) (Fig. 3 e) is a cosmopolitan species, wellknown and very common in the Baltic Sea and the German Bight. Being a species of large dimensions, it contributed greatly to the total biomass of Tintinnina. The lorica is cylindrical, does not have encrustations, and the ratio between length and diameter is high, around 8 . The peduncle is long and wide, surpassing by $1 / 5$ the total length. The oral aperture is serrated or denticulate. Rings with the same serrated structure are observed for the whole upper third of the lorica, probably as a result of successive depositions during its growth cycle.

Family Ptychocylidae Kofoid \& Campbell, 1929

Favella ehrenbergii (Claparède \& Lachmann, 1858) (Fig. $3 \mathrm{f}$ ). The description of $F$. helgolandica given by Hofker (1931) corresponds exactly to the specimens found in this 


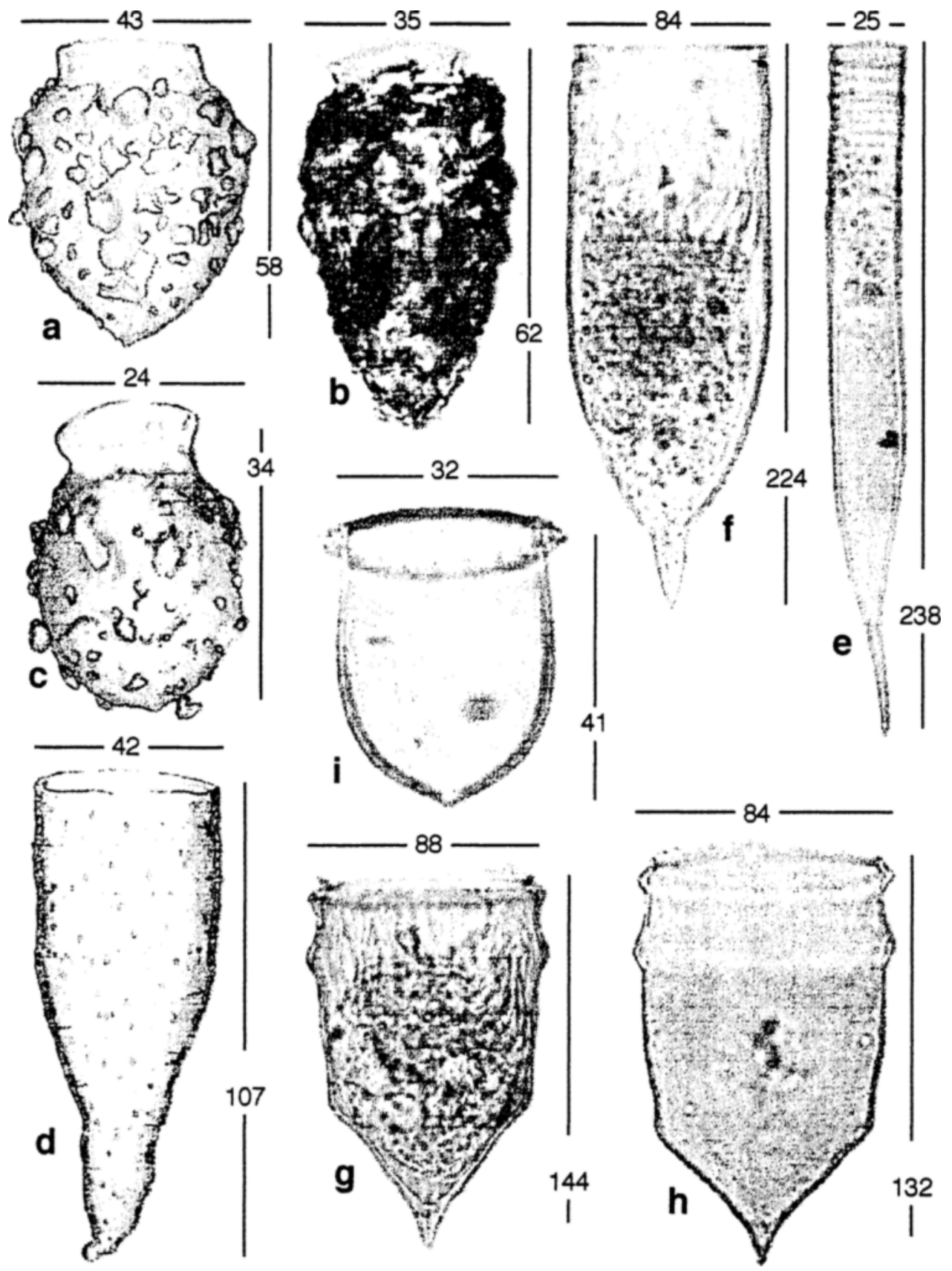

Fig. 3. Codonellopsidae, Stenosemella nivalis (a), S. producta (b), Codonellopsis ovata (c); Coxliellidae, Coxliella pseudoannulata (d), Helicostomella subulata (e); Ptychocylidae, Favella ehrenbergii (f), Ptychocylis umula (g), P. urnula (minor) (h); Petalotrichidae, Acanthostomella norvegica (i). 
investigation; but for reasons which will be explained hereafter, the name $F$. ehrenbergii was retained. The lorica is larger than that of the other species (Table 1), the shape is cylindrical with a ratio between length and diameter of 2.7. A slight constriction occurs in the oral aperture, together with a variable number of rings, which are superimposed during growth. The aboral cone is round, starting approximately from a third of the length and terminating in a peduncle which in general attains $1 / 7$ of the total length. The walls of the lorica are thick but hyaline, without particle accumulation but of a coarse texture.

Favella sp. (not illustrated). Only one specimen found; the lorica was covered with an unknown material, possibly oil, which made the identification to species level impossible.

Ptychocylis urnula (Claparède \& Lachmann, 1858) (Fig. 3 g-h). P. urnula was widely distributed throughout the North Sea, contributing largely to the total biomass of the Tintinnina. The lorica is identified by its cylindrical shape, with a small enlargement under the oral aperture and by the conical shape in the aboral region which terminates with a short peduncle. In vertical section, the cone ridge forms an angle of approximately $45^{\circ}$ with the cylinder wall. The edge of the oral aperture is serrated and the sides of the whole lorica show a certain rugose texture. The proportion between the length and diameter is approximately 1.8 .

Family Petalotrichidae Kofoid \& Campbell, 1929

Acanthostomella norvegica (Daday, 1887) (Fig. 3 i). Species of small dimensions and very abundant along the Norwegian coast. The lorica is quite fragile and difficult to observe, the refraction of the lorica walls is very close to that of water. The inferior region is hemispheric with a small, aboral peduncle. The upper half forms a cylinder with a height approximately equivalent to half the total length. The oral aperture is denticulate on the margins and with a narrow flank underneath which encircles the oral opening.

Family Xystonellidae Kofoid \& Campbell, 1929

Parafavella denticulata (Ehrenberg, 1840) (Fig. 4 a) is the second largest species found in the ZISCH program. Small quantities occurred at 15 stations, the species was absent in the English Channel and the German Bight. The lorica is cylindrical and the walls show a typical pattern for this genus, similar to the honeycombs of a beehive. The oral aperture is denticulated and the base of the lorica terminates in a peduncle which attains approximately $1 / 7$ of total length. The length of the lorica is quite variable, despite the fact that the diameter of the oral region could be considered constant (Table 1), the length-diameter ratio varied from 2.4 to 4.8 .

P. elegans (Ostenfeld, 1899) (Fig. $4 \mathrm{~b}-\mathrm{f}$ ) showed the largest biomass on the west coast of Norway, becoming the dominant species in the region. The shape of the lorica is slightly variable but always keeps cylindrical-conical. The wall of the lorica shows hexagonal alveoli, and the oral aperture presents, in the most cases, denticles curving outwards. The peduncle is generally long and fine, attaining up to $1 / 3$ of the total length. The mean ratio between total length and diameter is around 3.4.

P. parumdentata (Brandt, 1906) (Fig. $4 \mathrm{~g}-\mathrm{h}$ ). Identification was based on the descriptions by Marshall (1969). The lorica is conical as in P. elegans, but of smaller proportions; 


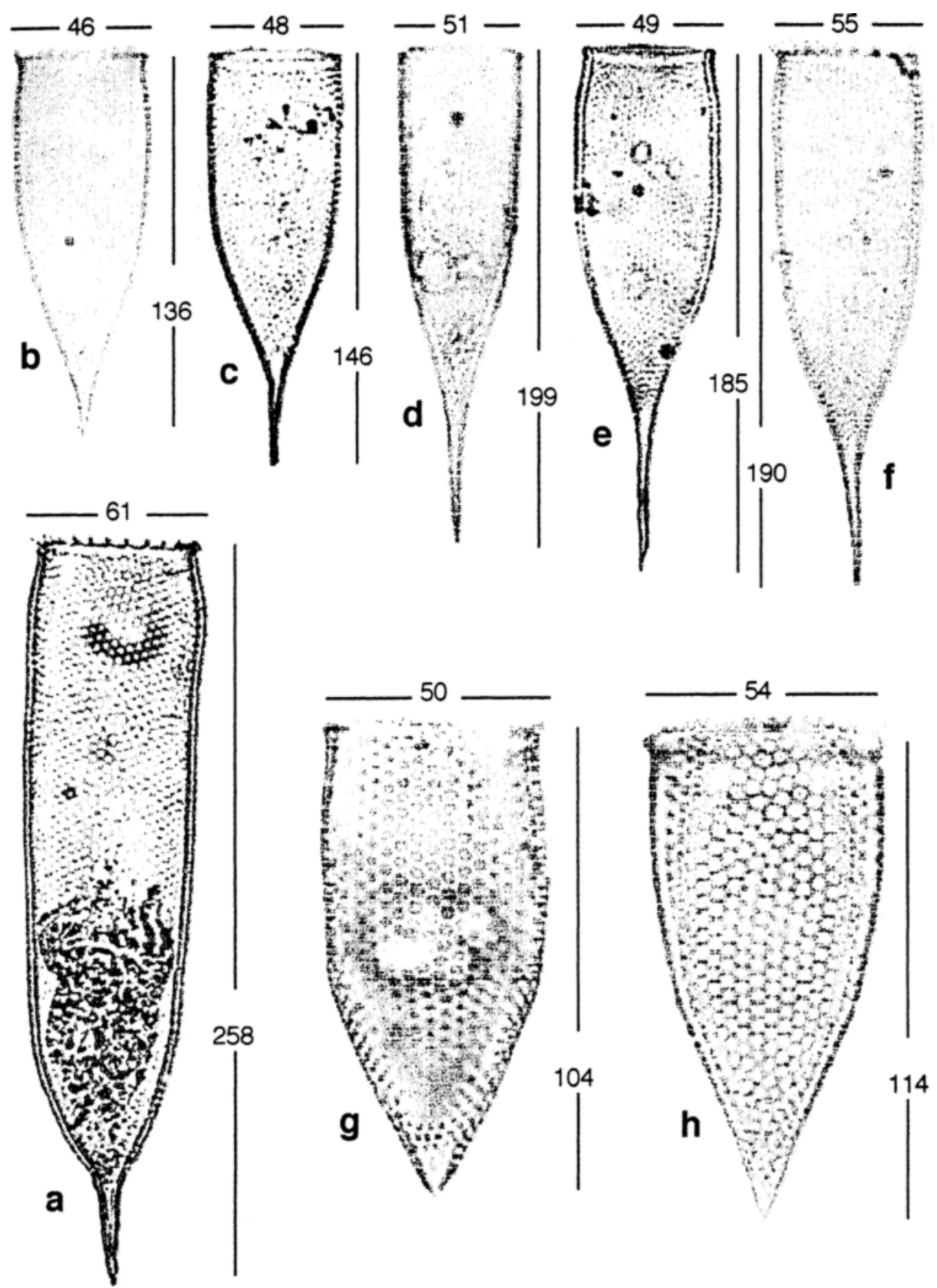

Fig. 4. Xystonellidae, Parafavella denticulata (a), P. elegans (b-f), P. parumdentata ( $\mathrm{g}-\mathrm{h})$. Distances in $\mu \mathrm{m}$ 
the walls show a honeycomb-like texture, as in all the other Parafavella. The peduncle is very short or absent and the margin of the oral aperture is serrated.

Parundella caudata (Ostenfeld, 1899) (Fig. 5 a). Few loricae of this species have been found, which up to the present time does not pose difficulties as to its taxonomy. $P$. caudata was found only in the Baltic Sea and on the coast of Norway, at stations 99, 101,105 and 115. The lorica is totally hyaline, with thick walls, without the presence of foreign material or striae, alveolus, etc. The shape of the lorica is that of an elongated cone, slightly curved, with a slight narrowing where the aboral peduncle starts, which attains approximately $1 / 5$ of the total length.

\section{Family Tintinnidae (Claparède \& Lachmann, 1858)}

Salpingella acuminata (Claparède \& Lachmann, 1858) (Fig.5 b-d) was present in neritic and oceanic areas in the northern half of the studied area, though not occurring in the Baltic Sea. The lorica is fine and hyaline, the oral aperture is dilated like that of a trumpet, being able to attain double the breadth of the lorica. The aboral cone is coiled as in Salpingacantha undata and the ratio between the length and diameter is 15.5.

Salpingacantha undata (Jørgensen, 1899) (Fig. $5 \mathrm{e}-\mathrm{f}$ ). Few loricae of this species were found, and were identified on the basis of the descriptions by Jørgensen (1899) and Marshall (1969). This species was also present only in the northern part of the studied area, mainly near the coasts of Scotland and Norway. The lorica is long and hyaline, with the aboral region generally being coiled to the right forming grooves in a spiral pattern. The oral margin is widened and denticulated in varying shapes and quantities. The length of the lorica attains on average 14 times its breadth.

The mean values of length, diameter and volume of the lorica of each identified species, as well as the number of measured individuals, are shown in Table 1.

\section{DISCUSSION}

The greatest difficulty in the identification of the material from the ZISCH program was due to the genus Tintinnopsis. Baker \& Phaff (1976) considered T. beroidea, T. minuta, $T$. nana, $T$. parvula and $T$. rapa variations of the same species. In the present work, T. parvula, T. nana and T. beroidea showed different shapes and sizes, and for this reason were considered separately in the evaluation of the biomass. Nevertheless, this does not invalidate the suppositions of Baker and Phaff, if we consider the degree of polymorphism already seen in the other genera, such as Favella (Laval-Peuto,1981), Ptychocylis (Schulz \& Wulff, 1929; Davis, 1981) and Cymatocylis (Wasik \& Mikolajczyk, 1994).

Some loricae found resembled those of T. rapa, which were attributed to T. parvula, since the volume of the lorica and the geographic distribution were similar. Our $T$. beroidea was similar to T. karajacensis Brandt (1906), which could be another synonym of this very polymorphic species. $T$. beroidea is one of the cosmopolitan species widely distributed both in tropical and temperate neritic waters of the world. T. tubulosa from ZISCH Program resembles also some specimens of $T$. lata Meunier, which were illustrated by Balech (1945). 
Table 1. Mean lorica dimensions and volume of the Tintinnina of ZISCH program

\begin{tabular}{|c|c|c|c|c|c|}
\hline Species & Dimension & $\begin{array}{c}\text { Mean } \\
(\mu \mathrm{m})\end{array}$ & $\begin{array}{l}\text { Standard } \\
\text { deviation }\end{array}$ & $\begin{array}{c}n \\
\text { (ind.) }\end{array}$ & $\begin{array}{l}\text { Lorica volume } \\
\qquad\left({\left.\mu \mathrm{m}^{3}\right)}^{3}\right.\end{array}$ \\
\hline \multirow[t]{2}{*}{ Leprotintinnus pellucidus } & diameter & 38 & 2 & 11 & 276.271 \\
\hline & length & 244 & 62 & 10 & \\
\hline \multirow[t]{2}{*}{ Tintinnopsis beroidea } & diameter & 35 & 4 & 64 & 71.611 \\
\hline & length & 86 & 17 & 64 & \\
\hline \multirow[t]{2}{*}{ T. cf cylindrica } & diameter & 40 & & 1 & 154.818 \\
\hline & length & 154 & & 1 & \\
\hline \multirow[t]{2}{*}{ T. nana } & diameter & 25 & 5 & 2 & 24.554 \\
\hline & length & 63 & 1 & 2 & \\
\hline \multirow[t]{2}{*}{ T. parvula } & diameter & 27 & 2 & 64 & 15.293 \\
\hline & length & 50 & 6 & 65 & \\
\hline \multirow[t]{3}{*}{ T. cf spiralis } & diameter & 29 & & 1 & 53.661 \\
\hline & length & 91 & & 1 & \\
\hline & oral diam. & 36 & & 1 & \\
\hline \multirow[t]{2}{*}{ T. tubulosa } & diameter & 43 & 2 & 7 & 99.216 \\
\hline & length & 78 & 6 & 7 & \\
\hline \multirow[t]{2}{*}{ Tintinnopsis sp. } & diameter & 31 & 9 & 10 & 26.841 \\
\hline & length & 53 & 13 & 10 & \\
\hline \multirow[t]{3}{*}{ Stenosemella nivalis } & diameter & 40 & 3 & 107 & 43.256 \\
\hline & length & 54 & 4 & 106 & \\
\hline & oral diam. & 25 & 2 & 66 & \\
\hline \multirow[t]{3}{*}{ S. producta } & diameter & 39 & 5 & 6 & 50.964 \\
\hline & length & 66 & 5 & 6 & \\
\hline & oral diam. & 23 & 6 & 5 & \\
\hline \multirow[t]{3}{*}{ Codonellopsis ovata } & diameter & 30 & 3 & 2 & 18.850 \\
\hline & length & 40 & 8 & 2 & \\
\hline & oral diam. & 19 & 4 & 2 & \\
\hline \multirow[t]{2}{*}{ Coxliella pseudoannulata } & diameter & 48 & 5 & 7 & 110.050 \\
\hline & length & 106 & 10 & 7 & \\
\hline \multirow[t]{2}{*}{ Helicostomella subulata } & diameter & 24 & 1 & 73 & 59.931 \\
\hline & length & 185 & 40 & 73 & \\
\hline \multirow[t]{2}{*}{ Favella ehrenbergii } & diameter & 86 & 4 & 8 & 904.227 \\
\hline & length & 234 & 17 & 8 & \\
\hline \multirow[t]{2}{*}{ Favella sp. } & diameter & 91 & & 1 & 740.230 \\
\hline & length & 194 & & 1 & \\
\hline \multirow[t]{2}{*}{ Ptychocylis urnula } & diameter & 85 & 6 & 58 & 641.826 \\
\hline & length & 151 & 9 & 57 & \\
\hline \multirow[t]{2}{*}{ Acanthostomella norvegica } & diameter & 29 & 2 & 36 & 23.291 \\
\hline & length & 42 & 5 & 37 & \\
\hline \multirow[t]{2}{*}{ Parafavella denticulata } & diameter & 57 & 6 & 12 & 783.007 \\
\hline & length & 197 & 73 & 12 & \\
\hline \multirow[t]{2}{*}{ P. elegans } & diameter & 50 & 4 & 26 & 634.512 \\
\hline & length & 168 & 26 & 26 & \\
\hline \multirow[t]{2}{*}{ P. parumdentata } & diameter & 49 & 2 & 15 & 157.585 \\
\hline & length & 115 & 15 & 15 & \\
\hline \multirow[t]{2}{*}{ Parundella caudata } & diameter & 42 & 1 & 6 & 65.469 \\
\hline & length & 121 & 5 & 6 & \\
\hline Salpingella acuminata & diameter & 18 & 2 & 26 & 59.879 \\
\hline & length & 279 & 27 & 26 & \\
\hline Salpingacantha undata & diameter & 18 & 1 & 11 & 55.483 \\
\hline & length & 256 & 22 & 11 & \\
\hline
\end{tabular}


The aboral region of our $T$. cf cylindrica is more regularly conical than the typical $T$. cylindrica, resembling also T. kofoidi Hada, 1938 and T. aperta Brandt, 1906, two very close species which seem to be highly polymorphic. Some loricae of $T$. aperta were pictured with a more prominent projection near the middle region, resembling some $T$. tocantinensis specimens. We have maintained our specimens as $T$. cf cylindrica but we believe it is very urgent to make a revision of the cylindrica-kofoidi-aperta-tocantinensis complex, which may be different morphotypes of the same species.

The species Codonellopsis ovata, first described by Jørgensen (1899) as a variety of Codonella lagenula (Codonella lagenula var ovata Jørgensen, 1899), was raised to the status of species by Kofoid \& Campbell (1929) who accepted as the type locality the Bergen Coast, Norway. It seems to be a rare species in the marine plankton. Other registers include some temperate and cold waters from the Gulf of California (Osório-Tafall, 1941; López-Ochoterena \& Roure-Cane, 1970), Angola (Silva, 1954) and South Shetland and Orkney Islands (Wasik \& Mikolajczyk, 1990). The characters which distinguish this species from C. contracta Kofoid \& Campbell, 1929, seem to be too subjective to support the division between these two taxa.

The specimens of $H$. subulata were found with a very constant oral diameter but with highly variable total lengths (Table 1). Cospers (1972) suggests that the extremely variable size of $H$. subulata is related to temperature.

The species Codonella nucula was described first by Fol (1884) and then transferred to the genus Tintinnopsis by Laackmann (1908). Jorgensen (1924) created the genus Stenosemmella in order to separate those Tintinnopsis which had a firmer lorica and a small oral collar; as such, the species that Fol (1884) had described began to be known as Stenosemella nucula. In the revision made by Kofoid \& Campbell (1929), S. nucula was rightly placed with the synonym $S$. nivalis described by Meunier (1910). However, Kofoid \& Campbell (1929) adopted the more recent name nivalis, which can be found in most publications that followed. Hofker (1931) redescribed this species and adopted the name $S$. nucula, but it remains dubious whether the original C. nucula of Fol is a Stenosemella, since the oral collar is absent in his picture. Thus, C. nucula could be in fact a still valid Tintinnopsis species, and for this reason we use the name $S$. nivalis as adopted by Kofoid \& Campbell (1929). Loricae with the characteristics of S. oliva Meunier (1910) were included in $S$. nucula.

Loricae of the genus Acanthostomella were found corresponding to those of A. norvegica and $A$. gracilis, but also intermediary forms were found. All the phenotypes of Acanthostomella were included in the taxon $A$. norvegica, in agreement with Balech (1971), who described the variations in the lorica of this species. This species is widely distributed in the cold waters of the Atlantic and Pacific Oceans (Hada, 1938) and is considered by Davis (1985) as a holarctic species.

Some loricae of the genus Parafavella were found which had the same shape as the loricae of $P$. edentata, which were included in $P$. elegans. The shape and the size of the lorica of both phenotypes are very similar and the diagnostic characteristic which would differentiate them would be the absence of a serrated crown circumferencing the oral aperture of the lorica in $P$ edentata. In the reference material, some loricae of $P$. elegans were found with part of the serrated crown loose. Lindley (1975) also mentioned the phenotype $P$. edentata, but included it in $P$. denticulata. Perhaps the absence of the serrated 
crown in $P$. elegans is part of the process of cellular division or lorica augmentation, where the cell withdraws the crown in order to include another piece, before secreting a new crown.

If Parafavella elegans shows a complex biological cycle, alternating the shape and size of the lorica, as observed in the closely related genus Favella (Laval-Peuto, 1981), could leave to supposition the taxon $P$. parumdentata, which also occurred at the stations with $P$. elegans, which is a morphotype of the latter. A few minutes after the cellular division the proter (or the trophont) starts the construction of a new lorica which resembles the shape of an adult, but it is smaller. While the variation in the lorica of $P$. elegans was observed (Fig. 4 b-f), it was also noted that the smaller specimens had a shape resembling P. parumdentata (Fig. $4 \mathrm{~g}-\mathrm{h}$ ), with a short peduncle in comparison with the larger specimens.

F. serrata (Möbius, 1887) and $F$. helgolandica (Brandt, 1906) are accepted here as synonyms of $F$. ehrenbergii. This decision was taken in agreement with Sassi \& Melo (1989), who included different phenotypes in $F$. ehrenbergii. The specimens found during the samplings of the ZISCH program showed a phenotype closer to $F$. serrata as illustrated by Marshall (1969) and $F$. helgolandica mentioned by Hofker (1931), without the presence of lamellas between the base of the lorica and the peduncle as in F. ehrenbergii of Brandt (1906). The name was defined according to priority: Tintinnus ehrenbergii Claparède \& Lachmann, 1858, Cyttarocylis serrata Möbius, 1887 and C. helgolandica Brandt, 1906. The genus Favella is due to Jørgensen (1924).

Laval-Peuto (1981) recognized Coxliella annulata and C. decipiens as polymorphic phases of $F$. ehrenbergii. This put in doubt the validity of the whole genus Coxliella and, consequently, all the family Coxliellidae. Inasmuch as C. pseudoannulata could also be a polymorphic phase of another species, in the present work this nomenclature was maintained, since the found loricae did not correspond to the size and shape of the descriptions of $C$. annulata or of $C$. decipiens.

The lorica with a denticulate oral aperture differentiates the genus Salpingacantha from Salpingella. However, if we imagine that Salpingacantha undata could retract the margins of the lorica and in so doing close the oral aperture, the result would be an oral aperture with thorn-like undulations as in Salpingella acuminata. Speculations aside, the fact remains that, excepting the thorn-like undulations, the loricae are extremely similar (Figs $5 \mathrm{~b}-\mathrm{d}, 5 \mathrm{e}-\mathrm{f}$ ), and besides this, the salinity, temperature, depth and sigma-T where the two species occurred are practically equal (Cordeiro et al., 1997). Salpingacantha undata and Salpingella acuminata may be different names of the same species.

The identification of Tintinnopsis cf spiralis was made with one unique specimen whose size and shape corresponded to the shape described by Marshall (1969), except for the absence of spiral striae. The presence or absence of striae is a taxonomical characteristic of dubious validity, since it is sometimes conditional to the availability of food (Capriulo et al., 1986). According to Marshall (1969), T. spiralis is restricted to the Arctic. However, the specimen was found at a depth of $300 \mathrm{~m}$, at the entrance of the Baltic Sea at temperatures below $4{ }^{\circ} \mathrm{C}$. The shape shown in Figure $2 \mathrm{f}$ could again be a specimen of $T$. parvula in cellular division, especially if we observe the illustrations of other species in division made by Hofker (1931): Tintinnopsis beroidea (p. 336, Fig. 17), Stenosemella ventricosa (p. 360, Fig. 36), Codonellopsis morchella (p. 366, Fig. 45). Given the impossibility to clarify this doubt and, for motives of biomass calculations, we preferred to accept the taxon $T$. cf spiralis. 


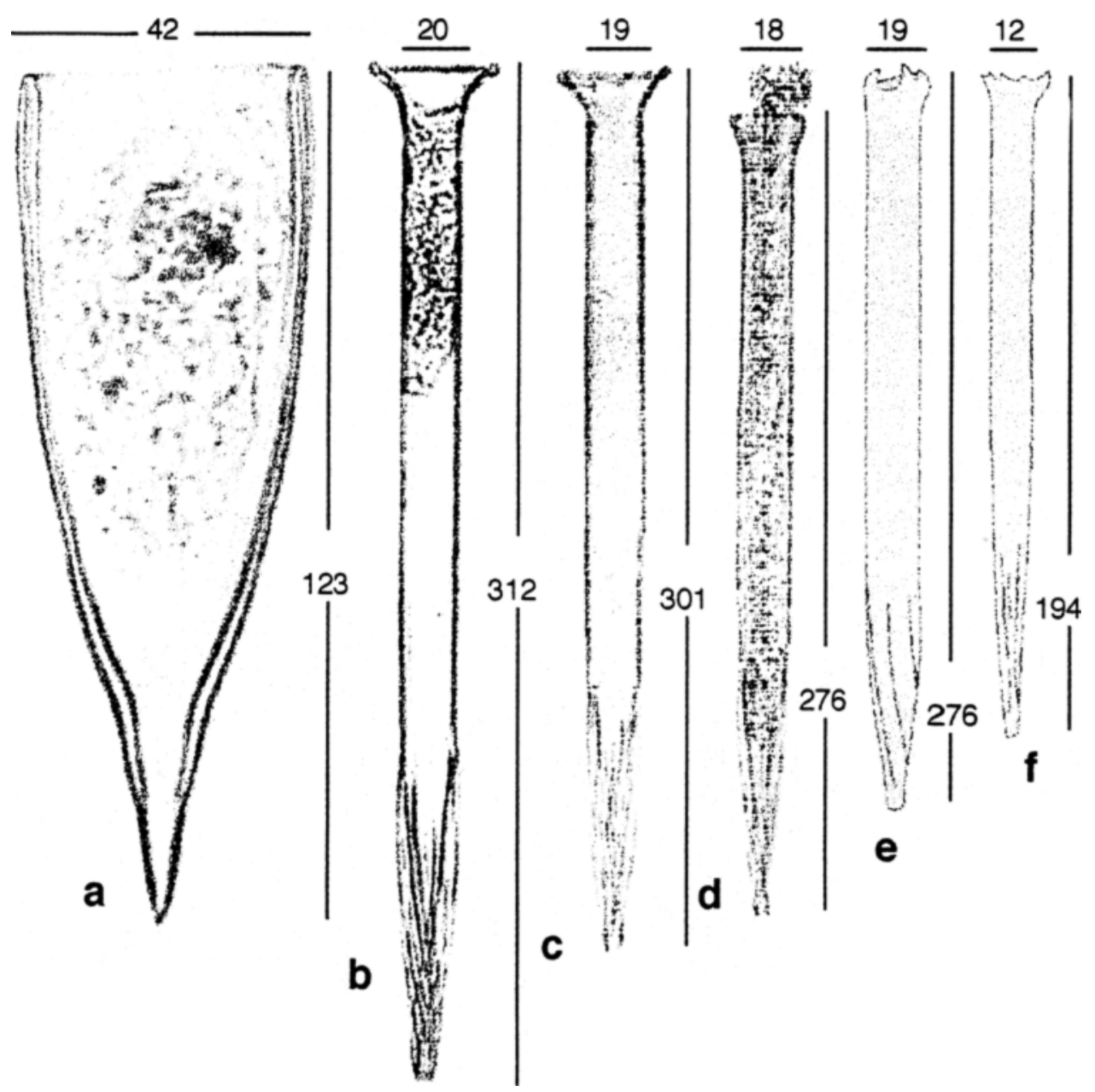

Fig. 5. Xystonellidae, Parundella caudata (a); Tintinnidae, Salpingella acuminata (b-d), Salpingacantha undata $(\mathrm{e}-\mathrm{f})$. Distances in $\mu \mathrm{m}$

The above-listed species, excepting $T$. cf spiralis, have already been registered in the North and Baltic seas and adjacent regions.

Lindley (1975) showed more recent data on seasonal and spatial distribution of Tintinnina in the North Sea, using material available from continuous plankton recorders (Hardy, 1941) towed by commercial ships during the year 1965. A comparison between the species found by Lindley and those of the present study was rendered difficult due to identification problems. But if we consider Favella serrata as synonym of $F$. ehrenbergii, Stenosemella spp. as being various names of $S$. nucula, and Tintinnopsis spp. as being species of Tintinnopsis identified in the ZISCH program, we would have at least 6 of the species found by Lindley (op. cit.) in the North Sea that were not identified during the 
Table 2. Species of Tintinnina found by Lindley (1975) in the North Sea, and a possible synonymity with the species found during the ZISCH program

\begin{tabular}{|ll|}
\hline Species found by Lindley (1975) & Species from ZISCH program \\
\hline Acanthostomella norvegica & $=$ \\
Dictyocysta elegans & not found \\
Codonellopsis lagenula & not found \\
Eutintinnus lususundae & not found \\
Parundella caudata & $=$ \\
Parafavella denticulata & P. urnula \\
Ptychocylis obtusa & $=$ \\
P. urnula & F. ehrenbergii \\
Favella serrata & $=$ \\
Helicostomella subulata & $P$. denticulata \\
Parafavella gigantea group & $=$ \\
Stenosemella spp. & not found \\
Tintinnidium mucicola & $=$ \\
Tintinnopsis spp. & $=$ \\
Coxliella pseudoannulata & not found \\
Cymatocylis spp. & not found \\
Epiplocylis acuminata & $=$ \\
Salpingella acuminata & \\
\hline
\end{tabular}

ZISCH program. The 18 taxa found by Lindley are shown in Table 2, where possible synonymity with the species of the ZISCH program is also shown.

The difference in the number of species found by Lindley and in the ZISCH program is due, in part, to the methods employed: a) Lindley carried out seasonal sampling; b) the Tintinnina are partially retained by the continuous sampler, which according to Zeitzschel (1966), retains only $3 \%$ of the large species such as $P$. gigantea and besides this, c) the continuous sampler collects at a relatively constant depth of $10 \mathrm{~m}$ and at a speed superior to 10 knots. On the other hand, the disagreeing results could be indicating an alteration in the local population, similar to that observed by Hagmeier (1978), Hagmeier \& Bauerfeind (1990) and Rick (1990) in the case of phytoplankton populations. These authors pointed out the growth of non-indigenous species, eutrophication processes and the increase in heavy-metal concentrations, respectively, as factors affecting the phytoplankton population structure.

\section{CONCLUSIONS}

A total of 23 species of Tintinnina was identified in the North Sea during the spring of 1986. However, future investigations on the taxonomy of the group could alter this number. Some doubts remain as to the validity of the taxa Tintinnopsis beroidea, T. parvula, T. nana, Parafavella parundentata, Coxliella pseudoannulata and as to the correct taxonomic position of Tintinnopsis sp.

Salpingacantha undata and Salpingella acuminata seem to be different names for one and the same species. This is also the case of $P$. urnula and P. parumdentata. 
$T$. beroidea and $T$. parvula were relatively common in coastal regions and could be important in the trophic chain, which increases the necessity for new taxonomic research.

There were differences between the results obtained previously by Lindley (1975) and those of the ZISCH program, which should be investigated further to determine whether these differences are due to methodological differences or to an alteration in the species composition of the Tintinnina in the North Sea, like that observed in the phytoplankton.

There exists a consensus between the present specialists that the taxonomy of the Tintinnina, considered the best known amongst the ciliates, is in urgent need of revision. The variability of shapes within a single species is very large and could lead to erroneous identifications. This revision should be performed with more comprehensive methods, including ecology, cellular morphology, laboratory cultivations versus field samples and comparisons at the molecular level.

Acknowledgements. Gratitude is due to Dr. Peter Martens, who supplied the material from the ZISCH program for the purpose of this study, as well as to Dr. Gotram Uhlig, at that time Director of the Biological Station of Helgoland, for logistic support in the analysis of the material, and to Drs Erik Hagmeier and Frederico Brandini for literature and suggestions concerning the text. Speciai thanks to the anonymous referees for the suggestions regarding the text. This work was financed by the German DAAD and by the Brazilian CAPES.

\section{LITERATURE CITED}

Baker, C. \& Phaff, W. J., 1976. Tintinnida from coastal waters of the S.W. Netherlands. I. The genus Tintinnopsis Stein. - Hydrobiologia 50, 101-111.

Balech, E., 1945. Tintinnoinea de Quequén. - Physis, 20 (55), 1-15.

Balech, E., 1971. Microplancton de la campaña oceanografica Productividad III. - Revta Mus. argent. Cienc. nat. Bernadino Rivadavia (Hidrobiol.) 3 (1), 1-282.

Brandt, K., 1906. Die Tintinnodeen der Plankton-Expedition. Tafelerklärungen. - Ergebn. Plankt.Exped. Humboldt-Stift. 3 La, 1-33.

Brandt, K., 1907. Die Tintinnodeen der Plankton-Expedition. Systematischer Teil. - Ergebn. Plankt.Exped. Humboldt-Stift. 3 La, 1-499.

Brownlee, D. C., 1977. The significance of cytological characteristics as revealed by protargol silverstaining in evaluating the systematics of the suborder Tintinnina. M. S, thesis, Dept. Zool., Univ. of Maryland, $146 \mathrm{pp}$

Campbell, A. S., 1942. The oceanic Tintinnoinea of the plankton gathered during the last cruise of the Carnegie. - Publs. Carnegie Instn 537, 1-163.

Candeias, A., 1932. Nota sobre algumas espécies de Tintinnoinea da costa norte de Portugal - Anais Fac. Ciênc. Porto 17, 163-175.

Capriulo, G. M., Taveras, J. \& Gold, K., 1986. Ciliate feeding: effect of food presence or absence on occurrence of striae in tintinnids. - Mar. Ecol. Prog. Ser. 30, 145-158.

Choi, J. Ki, Coats, D. W., Brownlee, D. C. \& Small, E. B., 1992. Morphology and infraciliature of three species of Eutintinnus (Ciliophora; Tintinnina) with guidelines for interpreting Protargol-stained tintinnine ciliates. - J. Protozool. 39, 80-92.

Cordeiro, T. A., Brandini, F. P. \& Martens, P., 1997. Spatial distribution of the Tintinnina (Ciliophora, Protista) in the North Sea, Spring of 1986 . J. Plankt. Res. (in press.)

Cospers, T. C., 1972. The identification of tintinnids (Protozoa: Ciliata: Tintinnida) of the St. Andrew Bay System, Florida. - Bull. mar. Sci. 22, 391-418.

Daday, E. von, 1887. Monographie der Familie der Tintinnodeen. - Mitt. zool. Stn Neapel 7, 473-591.

Davis, C. C., 1981. Variations of lorica shape in the genus Ptychocylis in relation to species identifications. - J. Plankt. Res. 3, 81-91.

Davis, C. C., 1985. Acanthostomella norvegica (Daday) in insular Newfoundland waters, Canada (Protozoa: Tintinnina). - Int. Revue ges. Hydrobiol. 70, 21-26. 
Foissner, W., 1994. Progress in taxonomy of planktonic freshwater ciliates. - Mar. microb. Food Webs $8,9-35$.

Fol, D. H., 1884. Sur la famille des Tintinnodea. - Recl Zool. Suisse, 1, 27-64.

Gaarder, K. R., 1946. Tintinnoinea from the "Michael Sars" North Atlantic deep-sea expedition, 1910. - Rep. scient. Results Michael Sars N. Atlant. Deep Sea Exped. 2, 1-37.

Gold, K., 1970. Cultivation of marine ciliates (Tintinnina) and heterotrophic flagellates. - Helgoländer wiss. Meeresunters. 20, 264-271.

Gold, K. \& Morales, E., 1975. Seasonal changes in lorica sizes and the species of Tintinnida in the New York Bight. - J. Protozool. 22, 520-528.

Hada, Y., 1938. Studies on the Tintinnoinea from the Western Tropical Pacific. - J. Fac. Sci., Hokkaido Univ. (Ser. 6: Zool.) 6 (2), 87-190.

Hagmeier, E., 1978. Variations in phytoplankton near Helgoland. - Rapp. P.-v. Réun. Cons. int. Explor. Mer. 172, 361-363.

Hagmeier, E. \& Bauerfeind, E., 1990. Phytoplankton. In: Warnsignale aus der Nordsee. Ed. by J. L. Lózan, W. Lenz, E. Rachor, B. Watermann \& H. v. Westernhagen. Parey, Hamburg, 102-111.

Hardy, A. C., 1941. General introduction to the 1938-39 survey. - Hull Bull. mar. Ecol. 2, 1-7.

Hofker, J., 1931. Studien über Tintinnoidea, - Arch. Protistenkde 75, 315-402.

Jørgensen, E., 1899. Über die Tintinnodeen der norwegischen Westküste. - Bergens Mus. Årb., 2 , $1-48$.

Jørgensen, E., 1924. Mediterranean Tintinnidae. - Rep. Dan. oceanogr. Exped. Mediterr. 2 (J.3), $1-110$.

Jørgensen, E., 1940. Ciliata, Tintinnidae. - Tierw. Nord- Ostsee 2c1, 1-26.

Kamiyama, T. \& Aizawa, Y., 1990. Excystment of tintinnid ciliates from marine sediment. - Bull. Plankt. Soc. Japan 36, 137-139.

Kofoid, C. A. \& Campbell, A. S., 1929. A conspectus of the marine and freshwater Ciliata belonging to the suborder Tinntinoinea, with descriptions of new species principally from the Agassiz Expedition to the eastern tropical Pacific, 1904-1905. - Univ. Calif. Publs Zool, 34, 1-403.

Kofoid, C. A. \& Campbell, A. S., 1939. Reports on the scientific results of the expedition to the eastern tropical Pacific, in charge of Alexander Agassiz, by the U.S. Fish Commission steamer "Albatross", from October 1904 to March 1905. The Ciliata: the Tintinnoinea. - Bull. Mus. comp. Zool. Harv. 84, 1-473.

Laackmann, H., 1908. Ungeschlechtliche und geschlechtliche Fortpflanzung der Tintinnen. - Wiss. Meeresunters. (Abt. Kiel) 10, 1-38.

Laval-Peuto, M., 1981. Construction of the lorica in Ciliata Tintinnina. In vivo study of Favella ehrenbergii: variability of the phenotypes during the cycle, biology, statics, biometry. - Protistologica $17,249-272$

Laval-Peuto, M. \& Brownlee, D. C., 1986. Identification and systematics of the Tintinnina (Ciliophora): evaluation and suggestions for improvement. - Annls Inst. océanogr. (N. S.) 62, 69-84.

Lindley, J. A., 1975. Continuous plankton records: a plankton atlas of the North Atlantic and North Sea: Supplement 3 - Tintinnida (Protozoa, Ciliophora) in 1965. - Bull. mar. Ecol. 8, 201-213.

López-Ochoterana, E. \& Roure-Cane, Ma. T., 1970. Lista taxonomica comentada de protozoarios de vida libre de Mexico. - Revta Soc. Mex. Hist. nat. 31, 23-68.

Marshall, S. M., 1969. Protozoa, Order: Tintinnida (some Families). - Cons. int. Explor. Mer., Zooplankt. sheet 125, 117-127.

Meunier, A., 1910. Microplankton des mers Barents et de Kara. Bulens, Bruxelles, 355 pp.

Meunier, A., 1919. Microplankton de la mer Flamande. Les Tintinnides. - Mém. Mus. r. Hist. nat. Belg. 8 (2), 1-59.

Möbius, K., 1887. Systematische Darstellung der Tiere des Planktons, gewonnen in der östlichen Ostsee und einer Fahrt von Kiel in dem Atlantischen Ozean. 5. - Ber. Kommn wiss. Unters. dt. Meere Kiel 1882-1886, 1-112.

Montagnes, D. J. S. \& Lynn, D. H., 1991. Taxonomy of choreotrichs, the major marine planktonic ciliates, with emphasis on the aloricate forms. - Mar. microb. Food Webs 5, 59-74.

Osório-Tafall, B. F., 1941. Tintinnidos nuevos o poco conocidos del plancton neritico de Mexico. Revta Soc. Mex. Hist. nat. 2, 147-173.

Pierce, R. W. \& Tumer, J. T., 1992. Ecology of planktonic ciliates in marine food webs. - Rev. aquat. Sci. 6, 139-181. 
Rick, H.-J., 1990. Ein Beitrag zur Abschätzung der Wechselbeziehung zwischen den planktischen Primärproduzenten des Nordseegebietes und den Schwermetallen Kupfer, Zink, Cadmium und Blei. Diss., Univ, Aachen, 234 pp.

Sassi, R. \& Melo, G. N., 1989. Hyaline Tintinnina (Protozoa-Ciliophora-Oligotrichida) from northeast Brazilian coastal reefs. - Bolm Inst. oceanogr., S. Paulo 37, 59-74.

Schulz, B. \& Wulff, A., 1929. Hydrographie und Oberflächenplankton des westlichen Barentsmeer in Sommer 1927. - Ber. dt. Kommn Meeresforsch. 4-5, 235-369.

Silva, E. S., 1954. Tintinnoinea do plancton marinho de Angola. - An. Junt. Inv. Ult. 10, 181-243.

Snyder, R. A. \& Brownlee, D. C., 1991. Nolaclusilis bicornis n.g., n.sp. (Tintinnina: Tintinnidiidae): a tintinnine ciliate with novel lorica and cell morphology from the Chesapeake Bay estuary. $-J$. Protozool. 38, 583-589.

Souto, S., 1981. Tintinnina. In: Atlas del zooplancton del Atlántico sudoccidental y métodos de trabajo con el zooplancton marino. Ed. by D. Boltovskoy. INIDEP, Mar del Plata, 353-381.

Utermöhl, H., 1958. Zur Vervollkommnung der quantitativen Phytoplankton-Methodik. - Mitt. int. Verh. theor. angew. Limnol. 9, 1-38.

Verity, P. G., 1987. Abundance, community composition, size distribution, and production rates of tintinnids in Narragansett Bay, Rhode Island. - Estuar. coast. Shelf Sci. 24, 671-690.

Wasik, A. \& Mikolajczyk, E., 1990. Tintinnids near Pack-Ice between South Shetland and the South Orkney Islands (26 Dec. 1988-18 Jan. 1989). - Acta Protozool. 29, 229-244.

Wasik, A. \& Mikolajczyk, E., 1994. Annual cycle of tintinnids in Admiralty Bay with an emphasis on seasonal variability in Cymatocylis affinis/convallaria lorica morphology. - J. Plankt. Res. 16, 1-8.

Zeitzschel, B., 1966. Die Verbreitung der Tintinnen im Nordatlantik. - Veröff. Inst. Meeresforsch. Bremerh. 2, 293-300. 